\title{
Recent Research at the Nigerian Institute of Social and Economic Research, University of Ibadan
}

AN account of the activities of the N.I.S.E.R., University of Ibadan, is given in its recently published Annual Report for $1962-3$. These include the following studies:

Social and economic change in Port Harcourt, by Dr. S. L. Andreski; including trends in employment and unemployment, the extent of engagement is secondary occupations, foodgrowing as a supplement to money incomes, saving, the adequacy of diets, housing, changes in traditional patterns of living and their degree of importance in employee attitudes, and the general problems associated with immigrant workers.

The social and economic history of the Cameroons, by Mr. E. W. Ardener; the changed political status of the former Southern Cameroons rendered it impracticable for Mr. Ardener to return to Buea, but his work on the local documentary sources was resumed under arrangements between the West Cameroon Government and the United Kingdom Department of Technical Co-operation.

Productivity of the Enugu coal mines, by Mr. W. M. L. Bispham; he has also completed a survey on the possibility of selling coal as domestic and industrial fuel in selected towns in Western and Northern Nigeria, caried out at the request of the Nigerian Coal Corporation.

Government activities to stimulate economic growth through aid to Nigerian private enterprise, by Dr. S. P. Schatz.

The oil-palm industry, by Mr. S. A. Adu.

A study of the Igala people, by Mr. J. S. Boston, for which the field-work has now been completed. Collation of the information collected was begun with an analysis of Igala oral tradition and other historical material. A paper summarizing some of the discoveries made was read to the conference of the Nigerian Historical Society held at Ibadan in December 1962. Mr. Boston also took part in discussions with the Northern Ministry of Agriculture on the oil-palm industry in Igala, on which he had previously made a report.

Socio-economic factors influencing the level of agricultural productivity, by Dr. P. von Blanckenberg, Dr. C. A. P. Takes, and Mr. O. Oloko. Rice farming in the Abakaliki area, rubber farming in the Benin area, and agriculture in Okigwi Division and Annang Province (Eastern Region) have been studied.

The economic history of Lagos in the latter part of the nineteenth century, by Mr. Spencer H. Brown.

A social-anthropological study of the Hausa community in Ibadan, by Dr. A. Cohen. Two censuses have been carried out and a study made of the organization of some categories of Hausa middlemen. The internal social organization of the community is being studied, particularly the relationship between members of the community and other Hausa in the Northern and Western regions, and the relationship with Yoruba individuals and groups in Ibadan.

The politics of the City of Ibadan, by Mr. G. Jenkins, as part of a comparative study with Dakar. The period covered, for Ibadan, is from the arrival of the British to the present.

The political geography of Bauchi Province, by Mr. M. C. Kirkeberg.

Indigenous trading patterns and institutions, with special reference to the role of women, by Miss G. A. Marshall. This includes an examination of economic transactions in the market places, the means by which traditional markets serve as centres of distribution of locally produced commodities and as media through which the local economies articulate with the world market. The work is now being written up in America.

The development of the Nigerian medical profession, by Mr. R. W. Morgan.

A study of the situation of the Nigerian intellectual, by Mr. C. J. Patterson.

Industrial workers in the Western Region of Nigeria, by Dr. E. J. Ryan. He will study the similarities and differences between the value and belief systems of workers in mechanized industry and those of groups in traditional occupations. 